\title{
Pour un commerce équitable avec le Tiers Monde : Enjeux et objectifs d'une action lancée par des œuvres d'entraide suisse
}

"Für Gerechten Handel mit der Dritten Welt”. Hintergründe und Forderungen einer Aktion schweizerischer Hilfswerke

\section{Richard Gerster}

\section{OpenEdition Journals}

Édition électronique

URL : http://journals.openedition.org/aspd/1250

DOI : $10.4000 /$ aspd. 1250

ISSN : 1663-9669

\section{Éditeur}

Institut de hautes études internationales et du développement

\section{Édition imprimée}

Date de publication : 1 janvier 1987

Pagination : 177-181

ISSN : 1660-5934

Référence électronique

Richard Gerster, « Pour un commerce équitable avec le Tiers Monde : Enjeux et objectifs d'une action lancée par des œuvres d'entraide suisse », Annuaire suisse de politique de développement [En ligne], 6 | 1987, mis en ligne le 09 mars 2013, consulté le 08 septembre 2020. URL : http:// journals.openedition.org/aspd/1250; DOI : https://doi.org/10.4000/aspd.1250

Ce document a été généré automatiquement le 8 septembre 2020

(c) The Graduate Institute I Geneva 


\section{Pour un commerce équitable avec le Tiers Monde : Enjeux et objectifs d'une action lancée par des œuvres d'entraide suisse}

„Für Gerechten Handel mit der Dritten Welt”. Hintergründe und Forderungen einer Aktion schweizerischer Hilfswerke

Richard Gerster

NOTE DE L'ÉDITEUR

Lire l'article original en allemand dans Schweizerisches Jahrbuch für Entwicklungspolitik: "„Für Gerechten Handel mit der Dritten Welt”. Hintergründe und Forderungen einer Aktion schweizerischer Hilfswerke », http://sjep.revues.org/1073. 